\title{
The water efficiency gap
}

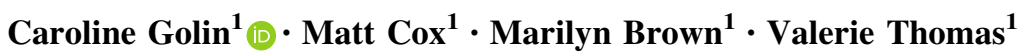

Received: 3 August 2015/Accepted: 31 August 2015/Published online: 1 October 2015

(C) Springer International Publishing 2015

\begin{abstract}
Water managers throughout the world are increasingly challenged to provide reliable and affordable water supplies to growing human populations, under conditions of climate variability and competing demands. At the same time, there is growing recognition of the interconnections between water and energy use (the waterenergy nexus), and calls for integrating water and energy policy. If any regulatory integration is to occur, it is important to understand the dynamics of water management and how it compares to the management of the energy system. Furthermore, lessons learned from the energy sector may transfer to the water sector. The concept of the energy efficiency gap has been used to understand the market and non-market barriers that create and sustain an inefficient energy system. We explore to what degree the understandings of the energy efficiency gap can be applied to water management to produce efficiency gains. Water systems typically fall far short of operating at economically and technically achievable levels of efficiency. We find that in many sectors of the economy, these failures are determined more by political institutions than by markets. To illustrate, even in times of scarcity, water management agencies typically do not raise prices. In contrast, most American energy resources are privately owned, and the market provides greater incentive for owners to consider scarcity in their decisions (Olmstead 2010). We argue that while there are substantial differences in the markets for energy and for water, there are many barriers to achieving
\end{abstract}

Caroline Golin

cburkhard3@gatech.edu

1 School of Public Policy, Georgia Institute of Technology, D. M. Smith Building, Room 107, 685 Cherry Street, Atlanta, GA 30332-0345, USA efficiency that are common to water and energy. Parallel opportunities for reducing the water efficiency gap include improved data reporting, improved metering, revised rate structures, improved information and management strategies, residential rebate programs, public-private partnerships for irrigation efficiency, benchmarks for thermoelectric cooling, and product efficiency standards.

\section{Keywords Water policy · Efficiency · Water-energy} nexus

\section{Introduction}

The increasingly interconnected nature of energy and water systems, often referred to as the water-energy-nexus, and the growing awareness of water scarcity has pushed policy makers to consider how to obtain greater efficiency gains from both water and energy and has created a call for greater policy integration and co-management. In the energy policy literature, decades of research documents the presence of an energy efficiency gap, that is, the space between the apparently economically achievable energy efficiency of the system relative to observed performance and investment (Hirst and Brown 1990; Jaffe and Stavins 1994). We are interested in whether a similar phenomenon exists within the water space and to what extent the lessons learned from studying the energy efficiency gap can translate to policy recommendations for increasing efficiency in the water market. The purpose of our paper is to first, identify barriers to efficiency in water resource allocation overall and as it relates to energy production and use; explore the relationship between the energy efficiency gap and the existence of a water efficiency gap, assess the implications that the existence of the gap holds for future 
policy; and finally identify the policy interventions suggested in the energy efficiency literature that may translate to the water market. Our primary motivation is to understand the complexity of efficient water management and explore what policy tools are relevant to increase water efficiency and any future integration of water and energy management. While we recognize that the efficient management of either resource, let alone the co-management, is highly complex and that our analysis is by no means exhaustive, we feel the conversation of how policy may shape the allocation of our natural resources should be couched in an understanding of both the barriers and limits of our institutions.

\section{Barriers to efficiency in the water market}

We begin this paper with an overview, albeit not exhaustive, of current barriers to efficiency in the water market overall and in relation to energy production. In our analysis we maintain the understanding that there exist two primary mechanisms to increase the efficiency of a system. The first is technology choice. Innovation over the past several decades has produced new infrastructure options for more efficient acquisition and conveyance of water as well as new options for more efficient end-use technologies. The second mechanism involves institutions-society's "rules of the game." With institutions, we are concerned with the set of choices presented to distributers and consumers that establish incentives or disincentives to act efficiently.

We also maintain that "market barriers" are obstacles that are not necessarily market failures but nonetheless contribute to inefficiency and slow the diffusion of waterefficient innovations. The market failure theory of public policy argues that public intervention in markets is only justified by the existence of market failures. "Government remedies are most suited to overcoming genuine market failures or government failures." ${ }^{1}$ Market failure occurs when the prices of goods and services give false signals about their real value. In general, externalities, public goods, monopolies, and information asymmetries are the most commonly recognized market failures, ${ }^{2}$ and in the water sector they are rampant. Thus, intervention in markets for water efficiency can be justified based on the market failures theory of public policy.

\footnotetext{
${ }^{1}$ U.S. Department of Energy (DOE) \& Committee on Climate Change Science and Technology Integration (CCCSTI) Strategies for the Commercialization and Deployment of Greenhouse Gas- Intensity Reducing Technologies and Practices. (Washington D.C.: U.S. Department of Energy, 2009), accessed January 22, 2015, http:// energy.gov/node/353617.

${ }^{2}$ Weimer, D. L. \& A. R. Vining, Policy Analysis: Concepts and Practice. (city: Prentice Hall, 2011).
}

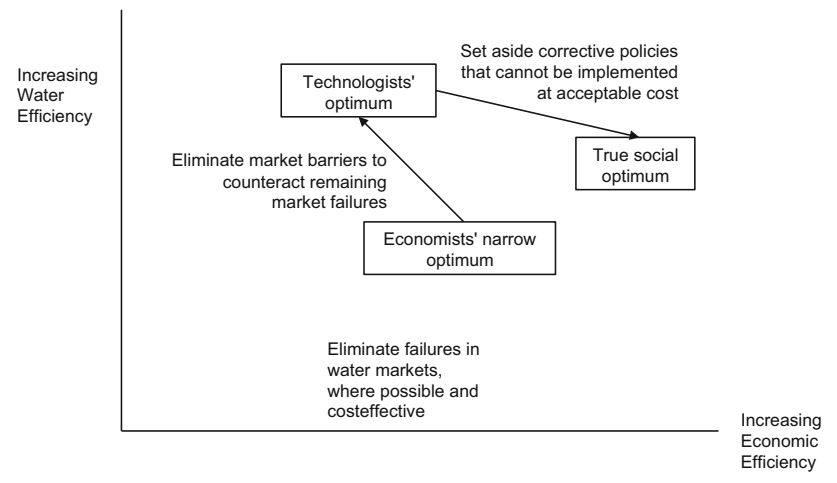

Fig. 1 Alternative notions of the water efficiency gap. (Source: Revised from Brown and Wang (2015))

However, the theory includes one qualification: feasible, low-cost policies must be available that can eliminate or compensate for these market failures. In these instances, policies can enable markets to operate more efficiently to the benefit of society (Fig. 1). In other instances, policies to eliminate market failures may not be feasible or cost effective, so policy analysts then turn to addressing alternative obstacles to water efficiency that could achieve an outcome similar to what might occur with the elimination of the market failure. Engineering professionals are generally optimistic about using such approaches, but choosing and supporting favored technologies run the risk of unintended consequences that sacrifice economic efficiency. Neoclassical economists would argue that the government should not intervene if the target is to reduce some other barrier. "Other types of barriers may be best addressed and resolved by allowing market forces to work." ${ }^{3}$ However, this tautological line of reasoning does not solve the problems created by market failures. As a result, we argue that it is valuable to examine both market failures and other barriers to achieve the social optimum shown in Fig. 1.

To investigate the barriers to efficiency, we organize our review along the lines of the water system cycle-acquisition, conveyance, and end-use. Within each segment of the water system we analyze institutional dynamics that are currently inhibiting efficient use and the technological choices for the three largest use-sectors of water-agriculture, residences, and thermoelectric power generation.

\section{Acquisition}

Acquisition is the 'process of obtaining water.' Two primary means of acquisition are surface water withdrawals

\footnotetext{
${ }^{3}$ U.S. Department of Energy (DOE) \& Committee on Climate Change Science and Technology Integration (CCCSTI) Strategies for the Commercialization and Deployment of Greenhouse Gas- Intensity Reducing Technologies and Practices. (Washington D.C.: U.S. Department of Energy, 2009), accessed January 22, 2015, http:// energy.gov/node/353617.
} 
and groundwater extraction. When assessing the efficiency of water acquisition, major issues of concern are regulatory uncertainty and a lack of information on water acquisition.

While the use of surface and groundwater has been heavily documented, the institutional dynamics that structure surface and groundwater acquisition has been given less attention. This is partially due to institutional diversity, both in arrangement and influence, in water acquisition for each region, state and acquiring party. Three major water legal doctrines dictate water acquisition-riparian use, prior appropriation, and reasonable use.

Under riparian laws, landowners have the right to the water on and adjacent to their land. If the water is used for natural use, meaning private use with no commercial gains, there are no additional fees or payment. When water is utilized for commercial gains, i.e., agriculture or thermoelectric, permits and an associated fee may be required. The use of water under this arrangement is essentially unlimited except when the water supply is deemed insufficient to satisfy the reasonable needs of all adjacent landowners. In such a case, landowners are supposed to reduce their use in proportion to their rights-sometimes based on the amount of adjacent land they own (CBO 2006). The resulting incentive is to own more land; generally, the more land a party owns, the more that party has control over and access to available water resources.

Under prior appropriation, water rights are separated from land ownership and the use of water can be sold or transferred for use on a different parcel of land, for a different purpose, at a different time, or with a change in the point of diversion. The first or prior person to use a quantity of water from a water source for a 'beneficial use' retains the right to continue use despite potential impacts on subsequent users. Subsequent users are only able to use the remaining water for 'beneficial use' purposes, provided that they do not impinge on the rights of prior users (CBO 2006). The right to use water outside the originating watershed (in-stream or out-of-stream use) is state-specific; whether or not a minimum water level is mandated, can have significant impacts on the reliability of water supply and the efficiency of use of the acquiring party.

Under reasonable use, groundwater extraction is permitted so long as it is withdrawn for the "purpose of making reasonable use of the land from which it is taken" (Gisser 1983). The reasonable use clause provides that unused water, or water that was used wastefully, will no longer be part of the user's water right and would be available for appropriation by others. This can devolve into a 'use it or lose it' approach to water rights, and in some cases can provide an incentive for unnecessary water use and extraction.

In addition to legal differences in how a user may obtain water, there are also differences in how these three basic approaches to acquisition are applied. The primary example is the issuance of water permits. Some states require that all single-users (that are not connected to the central grid water system) apply for a water permit, which potentially subjugates the user to restrictions. Other states only require that large-scale users register permits, and some states do not require a permit at all. In states lacking clear governing systems, the default approach is to delineate between large-scale water acquisition and small scale, private acquisition, and regulate end-use differently. In West Virginia, surface and groundwater withdrawals are not regulated.

The result is that each state has a different combination of laws governing the acquisition of ground and surface water. For example, Texas manages its groundwater under 'rule of capture'; no permit is required for groundwater use, which allows free access to individual drilling and pumping of groundwater until the aquifer is exhausted. Arizona, the state with arguably the most extensive groundwater management system, has divided the state into sections, each requiring various availability-based stringencies of groundwater rights and permits for most groundwater pumpers.

The diversity of legal and management institutions across states is an issue because watersheds are not statedelineated. For surface water, these legal inconsistencies play out most in the thermoelectric power sector. For example, Georgia and Alabama, which share water sources for thermoelectric cooling, both adhere to riparian laws for water acquisition-landowners have the right to the water on and adjacent to their land. And both states require users who have the capacity to withdraw an average of more than $378.54 \mathrm{~m}^{3}$ (100,000 gallons) per day to provide information to the state concerning their legal usage status. This means that any user withdrawing less than $378.54 \mathrm{~m}^{3}$ (100,000 gallons) per day is not responsible for reporting usage. For example, small, natural gas combined cycle power plants withdraw on average $283.9 \mathrm{~m}^{3}$ (75,000 gallons) per day, and are not required to report usage (Macknick et al. 2012). However, the two states enforce their reporting laws differently. Alabama requires users to register with the Alabama Office of Water Resources primarily for informational use but does not require users to obtain a permit for withdrawal or conduct a feasibility analysis to determine new use impacts on existing water use downstream and in other watersheds, unlike Georgia. The result is that Alabama has very little information on how water is acquired in the thermoelectric sector or how it impacts other sectors of the economy or the environment.

The regulation of groundwater also serves as a barrier for efficiency (Rose 1990; CBO 2006), and in the context of energy production is most notably in agricultural withdrawal for irrigation of biofuels. One of the major 
differences between surface water acquisition and groundwater acquisition is the scale and volume of water acquired. Most large-scale water acquisition and distribution projects are from surface water and are for public use-meaning they are financed by state and federal funding, and are subject to state and federal laws and regulations. In the agricultural sector, the largest user of groundwater, acquisition is largely unregulated. This is because the agricultural sector is populated by small-scale, private conveyances (Dinar 1994), and therefore only regulated by county and occasionally state laws. When county laws are enforced, they typically require that any acquisition of groundwater be subject to 'reasonable use'. As explained previously, the doctrine of reasonable use may result in a 'use it or lose it' approach to water management. In essence, if a farmer does not utilize the full acquisition of water in 1 year, the amount allotted in the next year may decrease.

The regulation of surface and groundwater acquisition directly impacts the development of energy systems and supply. Understanding how inefficiencies in water management translate into trade-offs in the energy sector is important for any future regulatory integration. Water consumption for energy can vary enormously depending on the mix of fuels and the technologies employed. The way in which water rights and acquisition are structured can greatly impact the development of energy systems, and therefore future water consumption (Stillwell et al. 2010). For example, Stillwell et al. (2011) showed that shifts in water rights and the institutions guiding acquisition may have implications for the type of fuel source deployed and the development path of energy infrastructure. More work is needed in this area to further understand the relationship and feedbacks between water policy and management and energy development.

\section{Conveyance}

When assessing the efficiency of water conveyance systems, the major issues of concern are the gross amount of water loss and degradation of conveyance infrastructure, the lack of information on water loss, and distortionary fiscal policies.

Outdated and inefficient infrastructure is the primary reason for water loss in the U.S., which can range from 5 to $20 \%$ (USEPA 2009). The American Society of Civil Engineers (2011) estimated that every day, 2.6 billion $\mathrm{m}^{3}$ (7 billion gallons) of water, about $18 \%$, is lost in conveyance. This results in roughly 7.9 million $\mathrm{m}^{3}$ (2.1 trillion gallons) annually or $16 \%$ of our nation's daily water use. Piping is the area of greatest concern; traditionally made of iron, pipes corrode and degrade over time, resulting in leaks and ruptures. Furthermore, as pipes age, they are prone to mineral build up through a process known as tuberculation, which increases friction and causes unnecessary head loss (EPRI 2002). The American Water Works Association estimates that 850 water main breaks occur daily in the United States and that restoring the degrading pipes would cost over $\$ 1$ trillion, not including any demand growth on the system.

The USGS does not measure water loss directly, but groups all losses in with public use $\mathrm{e}^{4}$ because the majority of public use water is unmetered, making it difficult to distinguish between water that is lost or used. In addition to water lost through leaks, there is up to $20 \%$ of unaccounted or "non-revenue" water in distribution systems (CBO 2002). This unaccounted-for water includes accounting errors, unauthorized connections, malfunctioning meters and distribution systems, and authorized unmetered water use. Because of incomplete information regarding water loss, it is difficult to determine the appropriate price and infrastructure investment required.

Financial and regulatory barriers stifle investments in new pipes and better monitoring services. Over the past fifty years, water utilities have continually failed to take in adequate revenues for operating, maintaining, and replacing their water infrastructure (CBO 2006). Unlike other public utilities, water conveyance systems in the United States are primarily supplied by publicly owned and operated waterworks. This was not always the case. Private firms dominated US water supply throughout most of the 19th century (Masten 2011). In part, the large sunk costs and low salvage values associated with water conveyance systems deterred private investment and necessitated public ownership. However, Masten (2011) argues that disagreements over city-demanded expansions that were resisted by private water utilities, who felt they could not recover the costs of expansion, led to the shift in ownership.

The switch to public ownership that took place during the 1960s meant that expanding and maintaining conveyance was not reliant on financial returns alone. Instead, water conveyance could also be financed through property taxes or other general taxes, as is the case today. When these resources are insufficient, the federal government supports systems through various spending programs, such as the Drinking Water State Revolving Funds, loans and grants administered by the Rural Utilities Service of the Department of Agriculture, and through tax preferences (CBO 2006). For example, in 1999, federal and federally

\footnotetext{
${ }^{4}$ According to the EPA, a public water system (PWS) is a "system for the provision to the public of water for human consumption through pipes or other constructed conveyances, if such system has at least fifteen service connections or regularly serves at least twentyfive individuals." http://water.epa.gov/infrastructure/drinkingwater/ pws/pwsdef2.cfm.
} 
supported spending accounted for $10.8 \%$ of the total investment in water systems (CBO 2002). ${ }^{5}$ Even those few water utilities that have remained privately operated are subject to restricted margins and regulated pricing. The result is a system that is underpricing water; these subsidy programs provide a disincentive for investments in infrastructure replacement and efficiency gains (Wolff and Gleick 2002). The American Water Works Association (2012) estimates that the U.S. has an annual funding shortfall of $\$ 11$ billion for infrastructure replacement.

These financial barriers are heightened for the tens of thousands of small community water utilities in the U.S. Small conveyance systems lack the economies of scale of larger systems and are therefore further unable to cover infrastructure repairs or upgrades by marginal rate increases spread over a large population. Additionally, because a small population is often accompanied by lack of commercial revenue streams, small conveyance systems are often unable to obtain good bond ratings to finance water infrastructure projects (Gasteyer 2010).

\section{End-use}

When assessing the efficiency of end-use, the major issues of concern are incomplete information and principal-agent issues.

The literature consistently shows that residential end users are often largely unaware of their monthly water use or the benefits and paybacks of more efficient technologies (Bruvold and Smith 1988; van Vugt 2001; Trumbo and O'Keefe 2005; Gleick 2003) despite the fact that the potential for water savings from water efficient appliances and better water management programs have been well documented (Baumann et al. 1998; Fidar et al. 2010; Kenney et al. 2008; Lee et al. 2011; Millock and Nauges 2010; Olmstead and Stavins 2009). For example, Gleick (2003) estimated a potential $39 \%$ reduction in residential urban indoor water use and 25-40 \% reduction in outdoor water use could be achieved with technology improvements and better management practices. But there are also principalagent issues at play. In many rental properties in the United States, water is included in the rent or monthly fees, regardless of use. As a result, any potential for market-driven efficiency and conservation is muted; the incentive to

\footnotetext{
5 The GAO reported that federal support in 2000 included $\$ 1.5$ billion in project grants, nearly $\$ 2.2$ billion in SRF grants, and $\$ 780$ million in the face value of loans and loan guarantees from the Department of Agriculture, including the market-based rates that borrowers would otherwise have to pay. We should note that SRF grants do not flow directly to water systems but to state pools from which loans are made, and only a small portion of the face value of loans and loan guarantees represents a subsidy to the recipient water systems.
}

invest in efficient technologies is removed. Additionally, these tenants are almost never the ones choosing the waterregulating appliances deployed in the rental space, such as water fixtures, dishwashers, clothes washers, etc., which while a common instance of the principal-agent problem further exacerbates efficiency problems.

Legal barriers regarding the classification and use of water have prohibited the investment in more efficient water-use. Of note are legal barriers that prevent the practices of rainwater harvesting and greywater reuse. Rainwater harvesting is the use of rainwater for outdoor uses, plumbing, and, in some cases, consumption. Greywater refers to the reuse of water drained from baths, showers, washing machines, and sinks (household wastewater excluding toilet wastes) for irrigation and other water conservation applications. Garrison et al. (2011) estimated that the total potential for rooftop rainwater harvesting in eight major U.S. cities would be enough to meet the water supply needs of between 21 and $75 \%$ of that city's population each year. Unfortunately, many U.S. cities have no legal distinction between grey and black water, rendering most domestic reclamation efforts technically illegal. In the past decade, several states have pushed legislation allowing, defining, and clarifying when rainwater harvesting and greywater reuse can occur. The main opposition to rainwater harvesting and greywater reuse has been concerns over water-quality standards and limiting recharge of waterbodies. However, in 2007, the Colorado Water Conservation Board and Douglas County determined that only $3 \%$ of rain actually reached a stream or the ground, suggesting recharge concerns may be overstated (Leonard Rice Engineers 2007).

In the production of biofuels, there has been significant technological innovation for greater efficiency in irrigation, but adoption is stifled by financial and information barriers. Schaible (2012) estimates that half of irrigated cropland in the West still utilizes traditional, inefficient furrow gravity systems. The low adoption rate of efficient irrigation systems is a result of the $40-50 \%$ higher initial costs than center pivot systems (Schaible 2012). Another major barrier to efficient use in the agricultural sector is the prominence of unmetered consumption and the prevalence of per-area pricing mechanisms that produce major information barriers to efficiency (Smith and Tsur 1997; Johansson et al. 2002). Due to the high costs associated with implementing meter systems, central water authorities will often resort to a per unit area pricing scheme. Because neither the end-user nor the water utility has complete information on the value and use of water, farmers tend to underreport actual usage when water is priced volumetrically (Johansson et al. 2002).

Similarly, significant gains have been made in water-use efficiency in thermoelectric-power production. However, 
high capital costs often deter investment. For example, the capital cost of the dry cooling system ranges from $\$ 21$ to $\$ 26$ million for a combined-cycle plant compared to \$5.7 to $\$ 6.5$ million for wet cooling (Maulbetsch and Stallings 2012). Another issue is that dry cooling systems tend to be less energy-efficient, requiring more fuel per unit of electricity, which can in turn lead to higher air pollution and environmental impacts from mining, processing, and transporting the fuel, as well as higher electricity costs (UCS 2013).

\section{Is there a 'water efficiency gap'?}

The above overview suggests that regulatory uncertainty, state by state variation in permitting laws, distortionary fiscal policies such as the 'use it or lose it' approach to water acquisition, an overarching lack of information, high upfront costs, and principal-agent issues impede efficiency in water markets. Analogous barriers impede energy efficiency across the analogous spectrum of power generation, transmission and distribution, and end-use (Brown and Wang 2015).

However, there is a critical difference between the water and energy market in that water is (at least currently) not treated as a commodity. Historically, the United States' approach to water law and regulation has been premised on the belief that water was abundant. This is no longer the case, if it ever was; water is a finite and valuable resource and should be treated as such. Numerous analysts have argued that the most effective policy for fixing all the market barriers facing efficient water use would be to correctly commoditize water and develop frameworks for assessing the services of water supply (Bergstrom et al. 1996; Ward et al. 2007; Mansur and Olmstead 2012; Young and Loomis 2014). Despite decades of arguments for a market approach to water valuation, the empirical evidence shows that water markets, in the classical sense, still lack many of the conditions necessary for efficiency. As a result, the water market as it exists will inevitably be prone to consistent, persistent failures (Bjornlund and Mckay 2002: 788).

Under an efficient water pricing system, the supplier must be able to recover all of its costs, including fixed and variable costs. From that standpoint, the price of water is equal to the sum of the supply costs (the operation and maintenance costs and the capital costs) plus the opportunity costs, plus the associated economic, social and environmental externalities-the long run marginal cost. However, this is never the case. The literature has repeatedly noted that water prices, for residential as well as agricultural uses, lie well below the long run marginal cost (Sibly 2006; Timmins 2003; Hanemann 1997). Consider the fact that in the early 1990s, the Municipal Water
District of Southern California (MWD) was considering implementing water prices that reflected the escalating costs of acquiring future supplies and the full opportunity cost of water. The financial analysis revealed that these rates, in normal years, were $70 \%$ higher than rates designed to ensure that total utility revenue equaled total cost. In arid years, this percentage difference increased to $118 \%$ and as much as $254 \%$ in years when water supplies were $25 \%$ below normal (Hall 2000).

The literature also suggests that efficient irrigation technologies are more likely to be adopted when water rates are high (Ward and Pulido-Velazquez 2008). In the thermoelectric power sector, the high cost of investing in dry cooling is underpinned by the low water prices faced by thermoelectric power plants. While many thermoelectric power plants draw water from a local surface source, some acquire water from public supplies, groundwater sources, or sewage. In general, public supply is more expensive than water obtained from other sources because public supply is priced by volume, while the cost of directly acquiring surface water, either from an adjacent river or pond, typically only shows up in a permitting fee. Groundwater is also more expensive than surface water because of the additional costs of extraction and pumping. Yang and Dziegielewski (2007) found that power plants that directly acquired water from surface sources were less efficient than those acquiring from public supply or other sources. The decreased efficiency was partially attributable to the lower prices paid for directly acquired surface sources than for pumped or public water (Yang and Dziegielewski 2007).

Furthermore, water rates often do not reflect any externalities-economic, environmental or social-associated with the water's use. Economic externalities include the opportunity cost of attaining water and the economic externalities associated with consumption. In most cases, water is priced as if there is no opportunity cost associated with water, meaning no alternative uses or shortages. Environmental externalities can be both positive and negative. Examples of negative environmental externalities associated with water distribution may include damage to ecosystems due to over-extraction. Positive externalities include the development of catchment management activities for the purpose of supplying potable water (Van Bueren and Hatton MacDonald 2004). Negative social externalities include the potential for a few users to deplete a water supply and restrict potential economic development options for the many (Van Bueren and Hatton MacDonald 2004). An inherent issue with creating an efficient market lies in the ability to correctly price water. While it is clear that water prices do not begin to cover the cost of acquisition, distribution, treatment, or maintenance, they also do not account for other related costs-particularly environmental externalities. This is another barrier shared with the energy market. 
Both water and energy markets fail to reach the social optimum because neither adequately incorporates environmental externalities. The mechanics of how to correctly price water and energy are in themselves entire disciplines.

Indeed, the argument has been made that, unlike other natural resources, water should never be treated as a commodity and that in fact the commoditization of water is potentially inhumane. Commoditizing water like energy, is an ambiguous proposition: clearly that approach has not perfected energy markets, and we question to what degree commoditizing water would be able to account for the value of ecosystems and biodiversity. If policy makers and planners pursue the integration of energy and water management, they should recognize that many of the lessons learned from the energy efficiency literature will not directly translate to the water space. Without the commodity denominator, integrating the policy and management of the two may be inherently incoherent. Certainly investments in technological choice, greater awareness, and the elimination of price skewing policies can produce opportunities for greater efficiency in both. But in water markets, the institutional framework has eliminated the possibility of a purely market-driven assessment.

Can the use of a natural resource be allocated correctly without market forces? We do not have definitive answers to this question. But what we do know is that without correct pricing, the concept of efficient use will be defined not by supply and demand but by the prevailing regulatory landscape. More importantly, as we learned from Jaffe and Stavins (1994), if the purpose of examining the efficiency gap of any market is to identify desirable policy interventions, we need to understand the limit to which policy interventions can mitigate inefficient use and improve overall resource allocation. From our review it is apparent that there are several market barriers to efficient water use but that the capacity of policy interventions to improve efficiency is limited without first correctly determining its value and relating this value to the public. By not first correctly pricing water we run the risk of continually relying on government interventions, making increased efficiency dependent on regulatory actions. In a number of instances detailed in Ostrom's (1990) work on common pool resources and expanded upon by many others since, this has not proven as unlikely as it may seem at first blush; there may be hope yet for non-market institutions to reduce the size of the gap.

\section{Beyond the gap: addressing barriers to water efficiency}

Despite their structural market differences, the water and energy efficiency gaps can be shrunk by analogous policy interventions. The question remains, to what extent can water acquisition, conveyance and end use be made more efficient without commoditizing water in a way that reflects its real value? The following list highlights a few policy recommendations that can be shared between the water and energy space. Table 1 lists the policy recommendations and which sector and barriers they address.

\section{Improve data reporting and benchmarking}

Currently the EIA-860 and EIA-923 forms do not require by the generating units. Instead it only collects monthly and annual total net detailed water use reporting for power plants. The forms also do not require the gross generation generation by generator (and generating unit). When creating benchmarks, for total water use or flow, detailed water use as well as gross generation data is needed. Without better data reporting, it is difficult to determine potential efficiency gains. One of the easiest ways to increase thermoelectric power-plant water efficiency is by creating benchmarks of water usage rates.

In tandem, the EIA should further develop and refine water-use benchmarks for thermoelectric cooling. This process should be a collaborative effort between the electric power industry, local, state, and federal regulators. In order to create more useful benchmarks of water usage rates, the current EIA-860 form should include water-use metrics and gross generation data for each generator in a plant. From these benchmarks, policy makers could better define standards for the design and operation of wet-cooling systems. If this data were made public, as is the case with parts of other EIA forms, utilities and the public could compare water use efficiencies between utilities, creating a more-informed discussion regarding water efficiency.
Table 1 Summary of policy recommendations

\begin{tabular}{lll}
\hline Policy recommendation & Sector & Barrier \\
\hline Improved data reporting and benchmarking & Acquisition, end-use & Institutional \\
Improved metering & Conveyance, end-use & Technological \\
Decoupled water rate structures & End-use & Institutional \\
Consumer water-use information & End-use & Institutional \\
Investment in efficient irrigation & Acquisition, end-use & Technological \\
Efficiency standards & End-use & Institutional \\
\hline
\end{tabular}




\section{Investment in better metering}

Properly selected and maintained water meters are the most accurate and easiest method for providing accurate measurement of water applied and targeting areas of inefficiency. Meters will also help to determine pumping plant efficiency. Finally, meters can detect potential well, pump or irrigation system problems. Meters can vary widely in cost and capability. Simple impeller meters that can be used on smaller farms range from $\$ 40$ to 800 . More advanced metering technologies can cost upwards of $\$ 17,000$ (Schaible and Aillery 2012).

A number of policies are available to work towards this goal. Under the current policy regime, water has achieved the 1950s dream for nuclear power-it is too cheap to meter. Alternatives to increasing the price of water to producers may include government subsidies for meter installations by parties other than end-users, mandates for meter installations, or mandates with cost sharing between the government and producers. The shared costs option may best meet the equity concerns of policymakers while still achieving the goals of the policy.

Investing in monitoring and metering is the first step in fixing the nation's degrading water infrastructure, as there is no way to manage loss, locate degradation, or determine correct pricing mechanisms without knowing how much water is flowing in a system and for what uses. Recommendations for utilities should include investing in metering and leak detection sensor technologies for new installations and retrofits (AWWA 2001; Baird 2011; CBO 2002). The "Embedded Energy Water Pilot Programs" showed that the most efficient programs for water savings were those focused on leak detection and repair (ECONorthwest 2011).

\section{Revise water rate structures}

To ensure that utilities are able to invest in efficiency measures, policy makers should develop a legal framework that allows the flexibility for regular tariff resets, allowing for water rates to change in periods of drought, when retrofits are required, or when new infrastructure is needed. One long-term policy option is for regulators to permit the decoupling of water utilities. While decoupled rate structures for electric and gas utilities have existed in a number of states for many years, currently, California is the only state to decouple water utilities' fixed cost recovery from the volume of water sold. Despite mixed reviews on California's handling of the transition, the consensus is that decoupling has helped to promote a more efficient pricing mechanism, as it removes the incentive to promote higherquantity sales, and insures that investments in demand-side efficiency and conservation will not come at the expense of utilities' bottom lines. Under a decoupled system, utility revenues are based on a regulatory revenue target rather than on sales, with rate adjustments to compensate for actual revenues that are above or below the target.

\section{Information and management}

Developing water-use information such as water bills that identify volume of usage, rates and charges and providing free water audits to help residential and agricultural users will help users to better understand current water use and potential water savings. These should be financed by the providing utility, which if allowed to recoup efficiency investments or decoupled, will be more feasible. Ferraro et al. (2011) demonstrated that when consumers are more aware of their water use in comparison to others, they would take actions to reduce consumption. The analysis suggests that greater information as well as social norms may help to encourage more efficient use.

\section{Residential rebate programs}

Additionally, in the short-term, policymakers could incentivize water efficient technologies through the use of rebate programs. Recent international research has shown that the combination of state and local government rebate programs for water efficient fixtures have resulted in a large reduction in household water use (Beal et al. 2011). Miami-Dade County, FL, USA implemented rebates and unit exchange programs for showerheads, toilets and clothes washers. As a result, consumers experienced a 6-14\% reduction in water demand. Water savings for efficiency measures were about $10.9,13.3$ and $14.5 \%$ per household per day for the showerhead, toilet, and clothes washer programs, respectively.

\section{Public-private partnerships to invest in more efficient irrigation systems}

Improvements in inefficient irrigation systems may result in substantial water savings, often at relatively low cost. The USDA (2002) estimates that the greatest gains are in the least efficient systems-surface gravity systems. For example, an increase from 40 to $60 \%$ in application efficiency will yield greater water savings than an increase from 60 to $80 \%$ for the same crop. An increase from 40 to $60 \%$ could reduce applied water by one-third and can generally be achieved at lower cost through less expensive system modifications and management adjustments (USDA 2002).

\section{Efficiency standards}

Energy standards similar to Japan's Top Runner program, which requires that efficiency standards be set each year at 
the best performance value of each product currently on sale in the market, could be applied to toilets, showerheads, and washers. In the thermoelectric power-sector, efficiency standards for water withdrawal and consumption could incentivize investment in reducing water use through technology development or strong management practices. Furthermore, mandating that new building developments reach the EPA's current WaterSense standard will also support a market for more efficient technologies. For example, in 2013, the Colorado legislature introduced a bill requiring that beginning in September 2016 only toilets certified under the federal government's WaterSense program could be sold in Colorado.

\section{Synthesis and future research}

This investigation into the barriers facing efficiency in the water sector has identified parallels between the energy and water sectors in order to inform policy makers and managers. It is apparent that the water sector and the energy sector share similar barriers including regulatory uncertainty, lack of information, high cost of efficiency investments, and principal/agent issues, among others. Furthermore, many of the policy recommendations that have been made for closing the energy efficiency gap directly translate to the water sector.

The key difference is in the contrasting market structures: the market does not treat water as a commodity, while energy has been commoditized. As a result, policy interventions for efficiency in energy benefit from the classical understanding of economic efficiency. This is not to say that the energy sector is currently priced correctly and that the removal of a handful of barriers will result in the optimum social allocation, because significant environmental externalities are currently not present in market prices for energy. The same is true in water markets, but in addition the market does not treat water as a commodity, so its operation is less classically defined and is more a function of government design.

As a result, more research is needed, with a focus on case-by-case evaluations of individual policy options that have been proven in the energy sector but have not yet been tried in the water sector. How interventions in energy efficiency might translate into policies for water efficiency will depend on the various market and non-market signals that influence these two important resource-based sectors.

\section{References}

American Society of Civil Engineers (2011) Failure to act: the economic impact of current investment trends in water \& wastewater treatment infrastructure. http://www.asce.org/uploa dedfiles/infrastructure/failure_to_act/asce\%20water\%20report\% 20final.pdf

American Water Works Association (2012) Buried no longer: confronting America's water infrastructure challenge. http:// www.awwa.org/Portals/0/files/legreg/documents/BuriedNoLon ger.pdf

Arbués F et al (2003) Estimation of residential water demand: a stateof-the-art review. J Socio-Econ 32(1):81-102

Baird GM (2011) The silver bullet for aging water distribution systems? J AWWA 103:15

Barber NL (2009) Summary of estimated water use in the United States in 2005

Baumann DD, Boland JJ, Hanemann WM (1998) Urban water demand management and planning. McGraw-Hill, New York

Beal C, Stewart RA, Huang T, Rey E (2011) SEQ residential end use study. J Aust Water Assoc 38(1):80-84

Beider P, Tawil N (2002) Future investment in drinking water and wastewater infrastructure. Congress

Bergstrom JC, Boyle KJ, Job CA, Kealy M (1996) Assessing the economic benefits of ground water for environmental policy decisions

Bjornlund H, McKay J (2002) Aspects of water markets for developing countries: experiences from Australia, Chile, and the US. Environ Develop Econ 7(4):769-795

Brown MA, Wang Y (2015) Green savings: how policy and markets drive energy efficiency. Praeger, San Francisco

Bruvold WH, Smith BR (1988) Developing and assessing a model of residential water conservation. J Am Water Resour Assoc 24(3):661-669

Cavanagh SM et al (2002) Muffled price signals: household water demand under increasing-block prices

Cohen R et al (2004) Energy down the drain. Water Supply

Cooley $\mathrm{H}$ et al (2008) More with less: agricultural water conservation and efficiency in California. Oakland, California: Pacific Institute, September. Retrieved on May 302014

Dinar A (1994) Impact of energy cost and water resource availability on agriculture and groundwater quality in California. Resour Energy Econ 16:47-66

Dinar A et al (1997) Water allocation mechanisms: principles and examples. World Bank Publications

ECONorthwest (2011) Embedded energy water pilot programs. Prepared for CPUC. http://www.cpuc.ca.gov/NR/rdonlyres/ 47665F26-AC6D-4DE6-8D32-ADA261B1C101/0/ECODRAFT Water_Pilots_EMV_Report_.pdf

Ferraro PJ et al (2011) The persistence of treatment effects with norm-based policy instruments: evidence from a randomized environmental policy experiment. Am Econ Rev 101(3):318-322

Fidar A, Memon FA, Butler D (2010) Environmental implications of water efficient microcomponents in residential buildings. Sci Total Environ 408(23):5828-5835

Fthenakis V, Kim HC (2010) Life-cycle uses of water in US electricity generation. Renew Sust Energy Rev 14(7):2039-2048

Garrison N et al (2011) Capturing rainwater from rooftops: an efficient water resource management strategy that increases supply and reduces pollution. Natural Resources Defense Council, New York (Nov)

Gasteyer S (2010) Are small community water systems more at risk than other systems? http://www.nesc.wvu.edu/pdf/dw/publica tions/ontap/magazine/OTSPSU10_features/More_At_Risk.pdf

Gisser M (1983) Groundwater: focusing on the real issue. J Political Econ 91:1001-1027

Gleick PH (2003) Global freshwater resources: soft-path solutions for the 21st century. Science 302(5650):1524-1528 
Hall DC (2000) Public choice and water rate design. In: Dinar A (ed) The political economy of water pricing reforms. Oxford University Press, Oxford, pp 189-212

Hanemann WM (1997) Price and rate structures. In: Baumann DD, Boland JJ, Hanemann WM (eds) Urban water demand management and planning. McGraw-Hill, New York, pp 137-179

Hirst E, Brown M (1990) Closing the efficiency gap: barriers to the efficient use of energy. Resour Conserv Recycl 3(4):267-281

Hoffmann $J$ et al (2004) Estimating freshwater needs to meet 2025 electricity generating capacity forecasts. US Department of Energy/NETL. June

Jaffe AB, Stavins RN (1994) The energy-efficiency gap what does it mean? Energy Policy 22(10):804-810

Johansson RC et al (2002) Pricing irrigation water: a review of theory and practice. Water Policy 4(2):173-199

Kenney DS, Goemans C, Klein R, Lowrey J, Reidy K (2008) Residential water demand management: lessons from aurora, Colorado1. J Am Water Resour Assoc 44(1):192-207

Kibel PS, Tansel B, Balbin M (2011) The end of paper water: natural limits, unlimited demands and reliable supply. Proceedings of the 2011 California water law symposium

Lee M, Tansel B, Balbin M (2011) Influence of residential water use efficiency measures on household water demand: a four year longitudinal study. Resour Conserv Recycl 56(1):1-6

Leonard Rice Engineers M a A, Ryley Carlock and Applewhite (2007) A holistic approach to sustainable water management in Douglass County

Macknick J et al (2012) Operational water consumption and withdrawal factors for electricity generating technologies: a review of existing literature. Environ Res Lett 7(4):045802

Mansur ET, Olmstead SM (2012) The value of scarce water: measuring the inefficiency of municipal regulations. J Urban Econ 71(3):332-346

Masten SE (2011) Public utility ownership in 19th-century America: the "aberrant" case of water. J Law Econ Organ 27(3):604-654

Maulbetsch J, Stallings J (2012) Evaluating the economics of alternative cooling technologies. Power Eng 116(11):120-128

McNeill LS, Edwards M (2001) Review of iron pipe corrosion in drinking water distribution systems. J. AWWA 93(7):88-100

Millock K, Nauges C (2010) Household adoption of water-efficient equipment: the role of socio-economic factors, environmental attitudes and policy. Environ Resour Econ 46(4):539-565

Mittal AK (2010) Energy-water nexus: improvements to federal water use data would increase understanding of trends in power plant water use. DIANE Publishing, Collingdale

Office USCB (2006) How federal policies affect the allocation of water. Congress of the United States, Congressional Budget Office, Washington

Olmstead SM (2010) The economics of managing scarce water resources. Rev Environ Econ Policy 4(2):179-198

Olmstead SM, Stavins RN (2009) Comparing price and non-price approaches to urban water conservation. Water Resour Res 45(4)

Renzetti S (1992) Evaluating the welfare effects of reforming municipal water prices. J Environ Econ Manage 22(2):147-163

Rose CM (1990) Energy and efficiency in the realignment of common-law water rights. J Legal Studies 19:261-296

Schaible GD, Aillery MP (2012) Water conservation in irrigated agriculture: trends and challenges in the face of emerging demands. US Department of Agriculture, Economic Research Service, Washington

Sibly H (2006) Efficient urban water pricing. Aust Econ Rev $39(2): 227-237$
Smith RB, Tsur Y (1997) Asymmetric information and the pricing of natural resources: the case of unmetered water. Land Econ 73:392-403

Stillwell AS, Hoppock DC, Webber ME (2010) Energy recovery from wastewater treatment plants in the United States: a case study of the energy-water nexus. Sustainability 2(4):945-962

Stillwell AS, King CW, Webber ME, Duncan IJ, Hardberger A (2011) The energy-water nexus in Texas. Ecol Soc 16:2

Timmins C (2003) Demand-side technology standards under inefficient pricing regimes. Environ Resour Econ 26(1):107-124

Trumbo CW, O'Keefe GJ (2005) Intention to conserve water: environmental values, reasoned action, and information effects across time. Soc Nat Resour 18(6):573-585

United Nations General Assembly (2010) Resolution A/RES/64/292. General comment no. 15. The right to water. UN committee on economic, social and cultural rights, November 2002

U.S Department of Agriculture (2002) Irrigation water management. http://www.Applications/irrigationwater.pdf

U.S Department of Agriculture (2013) Budget summary and annual performance plan. Retrieved April 132014 from USDA Web site: http://www.usda.gov/

U.S Environmental Protection Agency (2009) Control and mitigation of drinking water losses in distribution systems. http://www.epa. gov/ogwdw/pws/pdfs/analysis_wa-03_water_loss_doc_final_ draft_v62.pdf

U.S Environmental Protection Agency (2012a) The importance of water to the U.S economy. Part 1: background report. public review draft. http://water.epa.gov/action/importanceofwater/ upload/Background-Report-Public-Review-Draft-2.pdf

U.S Environmental Protection Agency (2014) Indoor water use in the United States. http://www.epa.gov/WaterSense/pubs/indoor.html

Van Bueren M, Hatton MacDonald D (2004) Addressing waterrelated externalities: issues for consideration. A water policy workshop convened by the Australian agricultural and resource economics society, February 10

van Vugt M (2001) Community identification moderating the impact of financial incentives in a natural social dilemma: water conservation. Pers Soc Psychol Bull 27(11):1440-1449

Ward FA, Pulido-Velazquez M (2008) Water conservation in irrigation can increase water use. Proc Natl Acad Sci 105(47):18215-18220

Ward FA, Michelsen AM, DeMouche L (2007) Barriers to water conservation in the Rio Grande Basin

Weissman S, Miller L (2009) California public utilities commission's pilot program to exploit the nexus of energy efficiency and water conservation. Pac McGeorge Global Bus Dev LJ 22:257

Wolff G, Gleick PH (2002) The soft path to water. In: Gleick PH, Burns WCG, Chalecki EL, Cohen M, Kao Cushing K, Mann AS, Reyes R, Wolff GH, Wong AK (eds) The world's water 2002-2003: the biennial report on freshwater resources. Island Press, Washington, DC

Yang X, Dziegielewski B (2007) Water use by thermoelectric power plants in the United States. J Am Water Resour Assoc 43(1):160-169

Young RA, Loomis JB (2014) Determining the economic value of water: concepts and methods. Routledge, London 